
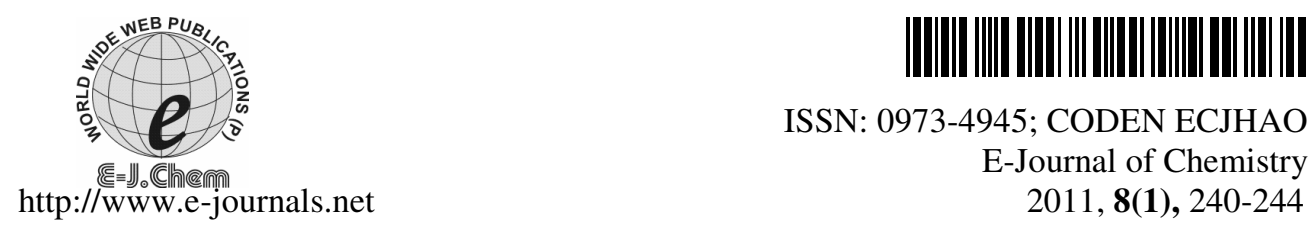

ISSN: 0973-4945; CODEN ECJHAO

E-Journal of Chemistry

2011, 8(1), 240-244

\title{
Syntheses of 2-(6'-Fluorobenzothiazol-2'-ylamino) -4, 6-(disubstituted thiouriedo)-1,3-pyrimidine Derivatives as Antimicrobial Agents
}

\author{
ANOOP K. PATHAK, VINEY CHAWLA and SHAILENDRA K. SARAF* \\ Faculty of Pharmacy, Northern India Engineering College \\ Sector-2, Dr. Akhilesh Das Nagar, Faizabad Road, Lucknow- 227105 \\ dirpharmniec@gmail.com
}

Received 29 April 2010; Accepted 17 July 2010

\begin{abstract}
A new series of 1,3-pyrimidine derivatives (3a-f) have been synthesized by reacting 2,4,6-Trichloropyrimidine with nucleophilic reagents 2amino-6-fluorobenzothiazole (1) in the presence of acetone. The (4,6- dichloropyrimidin-2-yl)-amine (2) so produced was then reacted to two moles of phenylthiourea derivatives to yield title compounds (3a-f). The structural assessment of the compounds (3a-f) was made on the basis of spectral data. The synthesized compounds were screened for their in vitro growth inhibiting activity against different strains of bacteria viz., B. subtilis, E. coli, $P$. aeruginosa and $S$. aureus using agar diffusion technique. Compounds $\mathbf{3 c}$ and $\mathbf{3 f}$ exhibited highest antibacterial activity.
\end{abstract}

Keywords: Fluorobenzothiazole, Pyrimidine derivatives, Phenyl thiourea derivatives, Antimicrobial activity.

\section{Introduction}

Pyrimidine is the most important member of all the diazines as this ring system occurs widely in living organisms. Purines, uric acid, alloxan, barbituric acid and a number of antimalarial and antibacterial drugs also contain the pyrimidine ring ${ }^{1,2}$. Thiazole ring system is quite common in natural products, since it can be produced by cyclization of cysteine residues in peptides ${ }^{3,4}$. The most important of these is Vitamin $B_{1}$ (thiamine), which contains both a pyrimidine and a thiazole ring system. The bleomycin antibiotics, which have antitumour properties, are complex aminoglycosidic structures containing thiazole units. Several semi-synthetic beta lactams contain 2-aminothiazole units in the side chain ${ }^{5,6}$.

Since benzothiazoles, pyrimidines and thioureas all possess diverse biological activities $^{7-11}$; the aim of this study was to synthesize some new derivatives incorporating these nuclei and evaluate the prepared compounds for antibacterial activity. 


\section{Experimental}

To 2,4,6 trichloropyrimidine $(18.3 \mathrm{~g}, 0.1$ mole $)$ dissolved in acetone $(100 \mathrm{~mL})$ cooled at $0{ }^{\circ} \mathrm{C}$, 2-amino-6 fluorobenzothiazole $(16.8 \mathrm{~g}, 0.1 \mathrm{~mole})$ dissolved in acetone $(100 \mathrm{~mL})$ was added with stirring at $0-5{ }^{\circ} \mathrm{C}$ followed by drop wise addition of sodium hydroxide (4.0 g, 0.1 mole) in water $(50 \mathrm{~mL})$. Contents were stirred for $3 \mathrm{~h}$ and poured into ice water, acidified with dilute hydrochloric acid, filtered, washed, dried and recrystallized from ethanol, melting range was $265-270^{\circ} \mathrm{C}$, yield was 53.94\%, IR ( KBr, $\left.\mathrm{cm}^{-1}\right):(3388>\mathrm{NH})$ and $\mathrm{MS}(\mathrm{m} / \mathrm{z}): 315\left(\mathrm{M}^{+}\right)$.

General procedure for synthesis of 2-(6'-fluorobenzothiazol-2'-ylamino)-4,6(disubstituted thiouriedo)-1,3-pyrimidines (3a-f)

Compound 2 (31.5 g, 0.1 mole) (Scheme 1) dissolved in acetone (100 mL) was added to substituted thiourea $(0.2$ mole $)$ in acetone $(100 \mathrm{~mL})$, slowly with constant stirring followed by addition of sodium hydroxide $(4 \mathrm{~g}, 0.1$ mole) in water $(50 \mathrm{~mL})$ and contents were refluxed for $2 \mathrm{~h}$ at $85-95{ }^{\circ} \mathrm{C}$. The mixture was poured into ice water, acidified with dilute $\mathrm{HCl}$, filtered, washed and recrystallized from ethanol and melting range was determined. 195-200 ${ }^{\circ} \mathrm{C}$, yield 39.83\%, IR $\left(\mathrm{KBr}, \mathrm{cm}^{-1}\right):(3446>\mathrm{NH}) ; 1120$ (thioureido CS); and MS $(\mathrm{m} / \mathrm{z})$ : $547\left(\mathrm{M}^{+1}\right)$.

\section{Spectral data of compound $\mathbf{3 a}$}

IR: $\left(\mathrm{KBr} \mathrm{cm}^{-1}\right)$ : 3230 (secondary amine N-H str), 1569 (secondary amine N-H ben), 3085 (Aromatic C-H str), 1622 (Aromatic $\mathrm{C}=\mathrm{C}$ str) 1282 (Aromatic amine C-N str), 1120 (Aromatic C-F str); MS (FAB) $\mathrm{m} / \mathrm{z}$ : 391(M-3). Yield $73.63 \%$, Melting range: $265-270{ }^{\circ} \mathrm{C}$. Compounds $\mathbf{3 b - f}$ were prepared by the aforesaid procedure ${ }^{12}$. The quantity of phenylthiourea derivatives was changed as per Table 1 .

Table 1. Quantities of different thiourea

\begin{tabular}{ccc}
\hline Compd.. & Name of substituent at R & Quantity \\
\hline 3b & Phenylthiourea & $30.4 \mathrm{~g}, 0.2$ mole \\
3c & 4-fluorophenyl thiourea & $34.0 \mathrm{~g}, 0.2$ mole \\
3d & 4-chlorophenyl thiourea & $37.2 \mathrm{~g}, 0.2$ mole \\
3e & 4-bromophenyl thiourea & $46.2 \mathrm{~g}, 0.2$ mole \\
3f & 4-nitrophenyl thiourea & $39.4 \mathrm{~g}, 0.2$ mole \\
\hline
\end{tabular}

\section{Compound $\mathbf{3 b}$}

IR: $\left(\mathrm{KBr} \mathrm{cm}^{-1}\right)$ : 3446 (secondary amine N-H str), 1569 (secondary amine N-H ben), 3072 (Aromatic C-H str), 1627 (Aromatic $\mathrm{C}=\mathrm{C}$ str), 1253 (Aromatic amine C-N str), 1012 (Aromatic C-F str) MS (FAB) $m / z: 547(\mathrm{M}+1)$.

\section{Compound $3 c$}

IR: $\left(\mathrm{KBr} \mathrm{cm}^{-1}\right)$ : 3446 (secondary amine N-H str), 1568 (secondary amine N-H ben), 3087 (Aromatic C-H str), 1620 (Aromatic $\mathrm{C}=\mathrm{C}$ str), 1255 (Aromatic amine C-N str), 1014 (Aromatic C-F str); MS (FAB) $m / z: 582(\mathrm{M}+$ ).

\section{Compound $3 \boldsymbol{d}$}

IR: $\left(\mathrm{KBr} \mathrm{cm}^{-1}\right)$ : 3434 (secondary amine N-H str), 1569 (secondary amine N-H ben), 3085 (Aromatic C-H str), 1623 (Aromatic $\mathrm{C}=\mathrm{C}$ str), 1255 and 1120 (Aromatic amine C-N str), 1014 (Aromatic C-F str), 804 (Aromatic C-Cl str); MS (FAB) m/z: 615 (M+11). 
Step 1<smiles>Clc1cc(Cl)nc(Cl)n1</smiles><smiles>Nc1nc2ccc(F)cc2s1</smiles>

2,4,6-Trichloro-pyrimidine

6-Fluoro-benzothiazol-2-ylamine

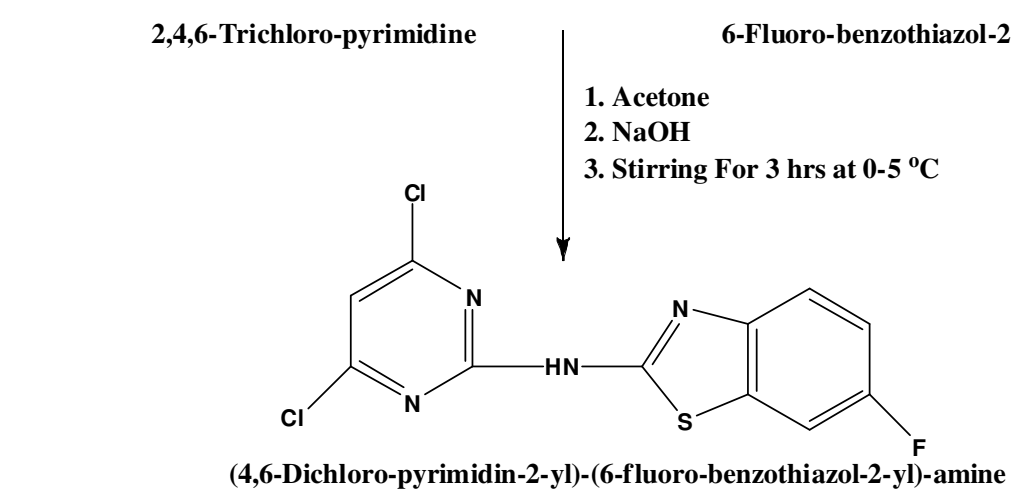

Step 2

(4,6-Dichloro-pyrimidin-2-yl)-(6-fluoro-benzothiazol-2-yl)-amine<smiles>[H][R14]([H])([H])CN[14CH2]N</smiles>

(4,6-Dichloro-pyrimidin-2-yl)-(6-fluoro-benz othiazol-2-yl)-amine

1. Acetone

2. $\mathrm{NaOH}$

3. Refluxed For 2 hrs at $85-90{ }^{\circ} \mathrm{C}$
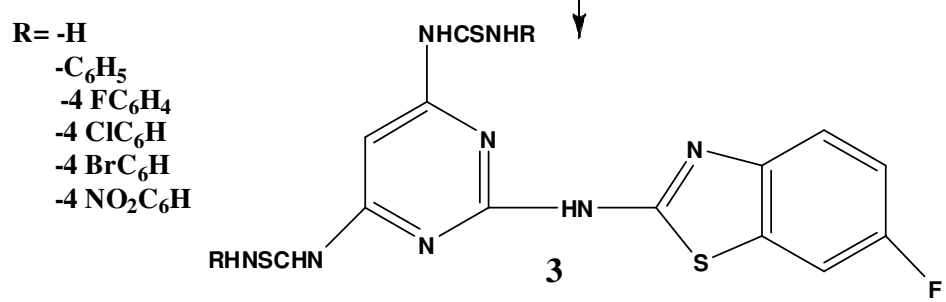

Scheme 1. Synthetic procedure for preparation of 2-(6'-fluorobenzothiazol-2'-ylamino)-4,6(disubstituted thiouriedo)-1,3-pyrimidine derivatives

\section{Compound $3 \boldsymbol{e}$}

IR: $\left(\mathrm{KBr} \mathrm{cm}^{-1}\right)$ : 3446 (secondary amine N-H str), 1568 (secondary amine N-H ben), 3087 (Aromatic C-H str), 1620 (Aromatic $\mathrm{C}=\mathrm{C}$ str), 1255 (Aromatic amine C-N str), 1014 (Aromatic C-F str); MS (FAB) $m / z: 703$ (M-1). 


\section{Compound $\mathbf{3 f}$}

IR: $\left(\mathrm{KBr} \mathrm{cm}^{-1}\right)$ : 3253 (secondary amine $\mathrm{N}-\mathrm{H}$ str), 1569 (secondary amine N-H ben), 3070 (Aromatic C-H str), 1623 (Aromatic C=C str), 1255 and 1120 (Aromatic amine C-N str), 1014 (Aromatic C-F str), 1521 and 1353 (symmetrical and asymmetrical aromatic NO str); MS (FAB) $m / z: 637(\mathrm{M}+1)$.

Purity of all the compounds was checked on silica gel G plates using iodine vapour and UV lamp (at short and long wavelength) as the detecting agent. Thin layer chromatography was used for monitoring the progress of reaction and product formation. Melting points of the synthesized compounds were taken by open capillary method and are uncorrected. The infra-red spectra of the synthesized compounds were recorded on a SHIMADZU FTIR 8400 spectrophotometer using potassium bromide pellets. The FAB mass spectra were recorded on a JEOL SX 102/DA6000 mass spectrometer/ data system using Argon/Xenon $(6 \mathrm{kV}, 10 \mathrm{~m} \mathrm{~A})$ as the FAB gas. The accelerating voltage was $10 \mathrm{kV}$ and the spectra were recorded at room temperature. The physical and analytical data of synthesized compounds is summarized in Table 2.

Table 2. Physical and analytical data of the synthesized compounds (3a -f)

\begin{tabular}{|c|c|c|c|c|c|c|c|c|c|}
\hline \multirow{2}{*}{ Compd. } & \multirow{2}{*}{$\mathrm{R}$} & \multirow{2}{*}{ Mol. formula } & \multirow{2}{*}{$\begin{array}{c}\text { Mol } \\
\text { Wt }\end{array}$} & \multicolumn{4}{|c|}{ Calculated } & \multirow{2}{*}{$\begin{array}{c}\text { Melting } \\
\text { Range, }{ }^{\circ} \mathrm{C}\end{array}$} & \multirow{2}{*}{$\begin{array}{c}\text { Yield, } \\
\%\end{array}$} \\
\hline & & & & C & $\mathrm{H}$ & $\mathrm{N}$ & $\mathrm{S}$ & & \\
\hline $3 \mathbf{a}$ & $\mathrm{H}$ & $\mathrm{C}_{13} \mathrm{H}_{11} \mathrm{FN}_{8} \mathrm{~S}_{3}$ & 394 & 39.6 & 2.8 & 28.4 & 24.4 & $260-265$ & 74 \\
\hline $3 b$ & $\mathrm{C}_{6} \mathrm{H}_{5}$ & $\mathrm{C}_{25} \mathrm{H}_{19} \mathrm{FN}_{8} \mathrm{~S}_{3}$ & 546 & 54.9 & 3.5 & 20.5 & 17.6 & $195-200$ & 40 \\
\hline $3 c$ & $4 \mathrm{FC}_{6} \mathrm{H}_{4}$ & $\mathrm{C}_{25} \mathrm{H}_{17} \mathrm{~F}_{3} \mathrm{~N}_{8} \mathrm{~S}_{3}$ & 582 & 51.5 & 2.9 & 19.2 & 16.5 & $260-265$ & 38 \\
\hline 3d & $4 \mathrm{ClC}_{6} \mathrm{H}_{4}$ & $\mathrm{C}_{25} \mathrm{H}_{17} \mathrm{Cl}_{2} \mathrm{FN}_{8} \mathrm{~S}_{3}$ & 626 & 48.8 & 2.8 & 18.2 & 15.6 & $245-250$ & 16 \\
\hline $3 e$ & $4 \mathrm{BrC}_{6} \mathrm{H}_{4}$ & $\mathrm{C}_{25} \mathrm{H}_{17} \mathrm{Br}_{2} \mathrm{FN}_{8} \mathrm{~S}_{3}$ & 704 & 42.6 & 2.4 & 15.9 & 13.7 & $240-245$ & 17 \\
\hline 3f & $4 \mathrm{NO}_{2} \mathrm{C}_{6} \mathrm{H}_{4}$ & $\mathrm{C}_{25} \mathrm{H}_{17} \mathrm{FN}_{10} \mathrm{O}_{4} \mathrm{~S}_{3}$ & 636 & 47.2 & 2.7 & 22.0 & 15.1 & $235-240$ & 60 \\
\hline
\end{tabular}

Antibacterial activity

Compounds 3a-f were screened for antibacterial activity against strains of Bacillus subtilis (MTCC 441), Pseudomonas aeruginosa (MTCC 424), Escherichia coli (MTCC 1573) and Staphylococcus aureus (MTCC 1430) using cylinder-plate method ${ }^{13}$. Culture media were prepared using aseptic and sterilization techniques ${ }^{14}$. Incubation period was $24 \mathrm{~h}$ at $37{ }^{\circ} \mathrm{C}$ in order to activate the bacterial strain. All the solutions of test compounds were prepared by dissolving $1 \mathrm{mg}$ of testing sample in $1 \mathrm{~mL}$ of $\operatorname{DMF}(N, N$-Dimethylformamide). This gives the conc. of sample $1000 \mu \mathrm{g} / \mathrm{mL}$ or $1000 \mathrm{ppm}$. Different dilutions such as $200 \mu \mathrm{g} / \mathrm{mL}$ and $100 \mu \mathrm{g} / \mathrm{mL}$ were prepared from the sample solution. A solution of DMF (10\%) was used as control. Pure cultures of Bacillus subtilis, Pseudomonas aeruginosa, Escherichia coli and Staphylococcus aureus were procured from Institute of Microbial Technology (IMTECH), Chandigarh, India and raised in conical flask $(100 \mathrm{~mL})$ containing potato dextrose agar (PDA). The evaluation of the antibacterial activity was done by measuring the zone of inhibition in different petri plates and taking average for each strain.

\section{Results and Discussion}

The compounds (3a-f) were synthesized by reacting 2,4,6-trichloropyrimidine with 2-amino6-fluorobenzothiazole yielding (4,6-dichloropyrimidin-2-yl-6-fluorobenzothiazol-2-yl)amine followed by reaction with two moles of phenylthiourea. The physical and analytical data of the compounds are presented in Table 2.

The yields of compounds fall in the range of $16 \%$ to $74 \%$. The spectral data (IR and MS) are in good agreement with their structures. Scanning results of antimicrobial activity (Table 3) reveal that the known standard antibiotic produced a zone of inhibition of the order 
of 20-23 mm. Compounds $\mathbf{3 c}$ and $\mathbf{3 f}$ displayed good activity against E. coli, P. aeruginosa, $B$. subtilis and $S$. aureus. This could be due to the presence of fluoro and nitro groups. Other compounds (3a, 3b, 3d and $\mathbf{3 f}$ ) exhibited less pronounced activity against the tested strains.

Table 3. Antibacterial screening data of compounds 3a-f

\begin{tabular}{ccccc}
\hline \multirow{2}{*}{ Compound } & \multicolumn{4}{c}{ Average diameter of zone of inhibition, in mm } \\
\cline { 2 - 5 } & E. coli & P. aeruginosa & B. subtilis & S. aureus \\
\hline 3a & 15 & 15 & 14 & 16 \\
3b & 18 & 16 & 13 & 16 \\
3c & 19 & 20 & 18 & 19 \\
3d & 14 & 15 & 12 & 16 \\
3e & 16 & 16 & 14 & 15 \\
3f & 19 & 19 & 15 & 15 \\
Standard (Ciprofloxacin) & 23 & 21 & 20 & 21 \\
Control (DMF) & 00 & 00 & 00 & 00 \\
\hline
\end{tabular}

\section{Conclusion}

A series of 1,3 pyrimidine derivatives have been synthesized and characterized on the basis of IR and MS spectral data. The compounds exhibited antibacterial activity with two compounds showing good activity against selected strains.

\section{Acknowledgment}

The authors are thankful to Central Drug Research Institute (CDRI), Lucknow for providing library facilities and spectral data.

\section{References}

1. Bansal K R, Heterocyclic Chemistry; $3^{\text {rd }}$ Ed., New Age Publishers, New Delhi, 1999, 450.

2. Gilchrist L T, Heterocyclic Chemistry; $3^{\text {rd }}$ Ed., Pearson Education, New Delhi, 2007, 319.

3. Desai P S and Desai K R, J Indian Chem Soc., 1994, 71,155.

4. Sharma K, Khatri V, Sareen V, Garg U and Taneja P, Indian J Heterocycl Chem., 2002, 12, 17.

5. Sawhney S N, Arora S K, Singh J V, Bansal O P and Singh S P, Indian J Chem., 1978, 16B, 605.

6. Douglass B I and Dains F B, J Am Chem Soc., 1934, 56, 1408.

7. Kenner G W, Reese C B and Todd A R, J Chem Soc., 1955, 20, 855-859.

8. Houminer Y, J Org Chem., 1985, 50, 786.

9. Rossi A, Schenone S, Angelucci A, Cozzi M, Caracciolo V, Pentimalli F, Puca A, Pucci B, La Montagna R, Bologna M, Botta M and Giordano A, The FASEB J., 2010, doi 10.1096/fj.09-148593.

10. Fathalla O A, Zeid I F, Haiba M E, Soliman A M, Abd-Elmoez Sh I and El-Serwy W S, World J Chem., 2009, 4(2), 127-132.

11. Dorsey J F, Jove R, Kraker A J and Wu J, Cancer Res., 2000, 60, 3127-3131.

12. Sareen V, Khatri V, Jain P and Sharma K, Indian J Chem., 2006, 45B, 1288-1290.

13. Indian Pharmacopoeia, 1996, Vol. II, A-100-105.

14. Garrod L P and Water Worth P M, J Clin Pathol., 1971, 24(9), 779-789. 


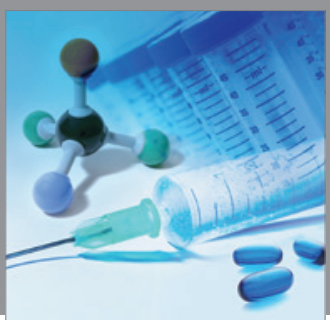

International Journal of

Medicinal Chemistry

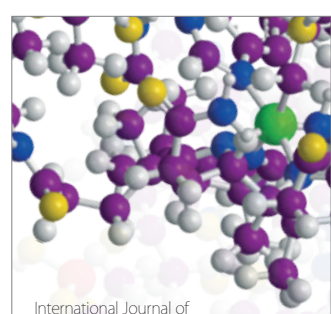

Carbohydrate Chemistry

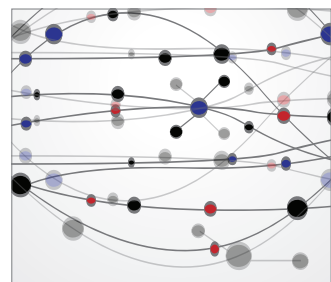

The Scientific World Journal
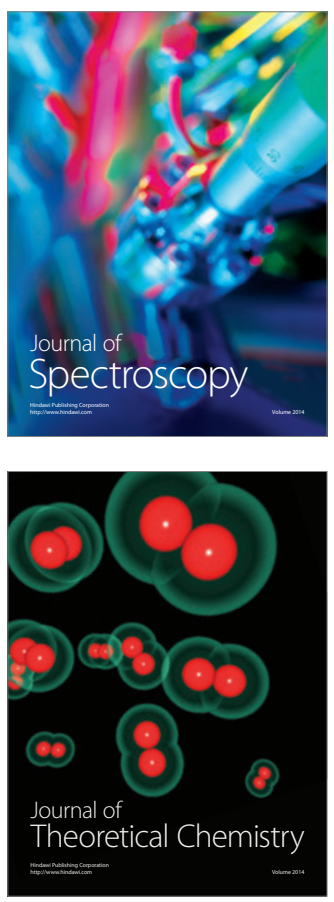
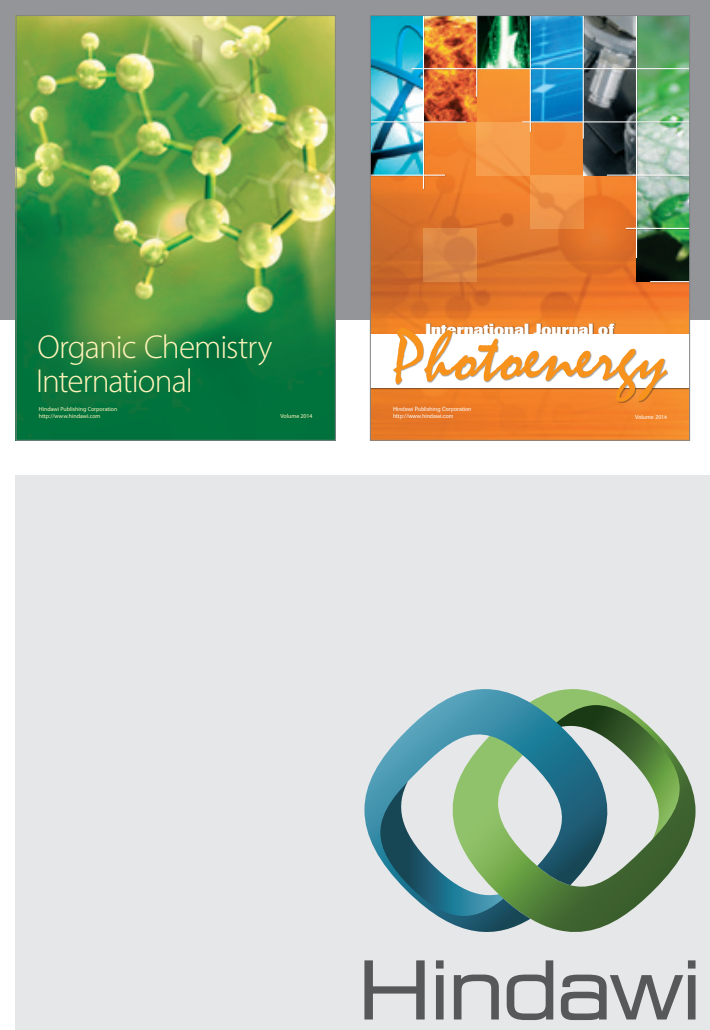

Submit your manuscripts at

http://www.hindawi.com
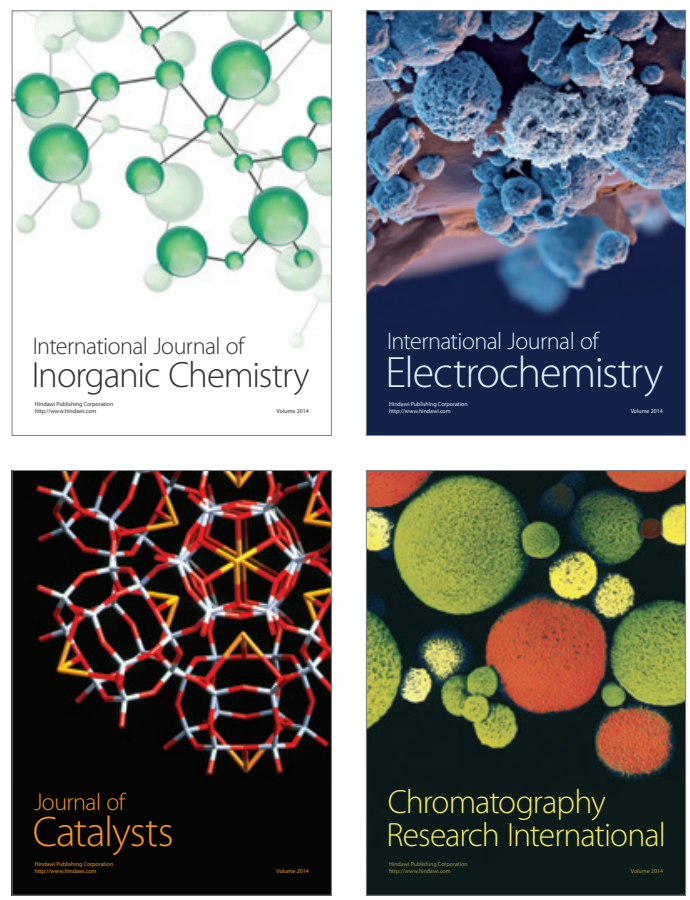
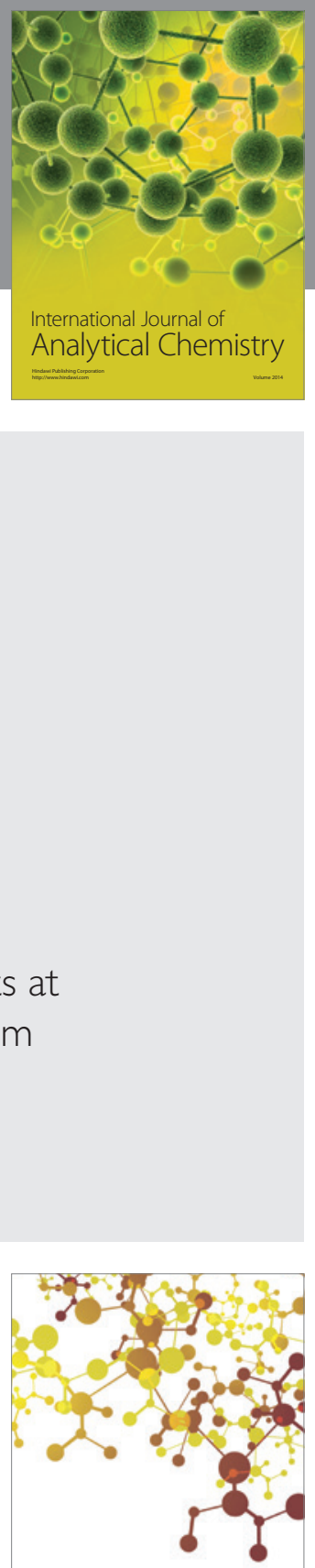

Journal of

Applied Chemistry
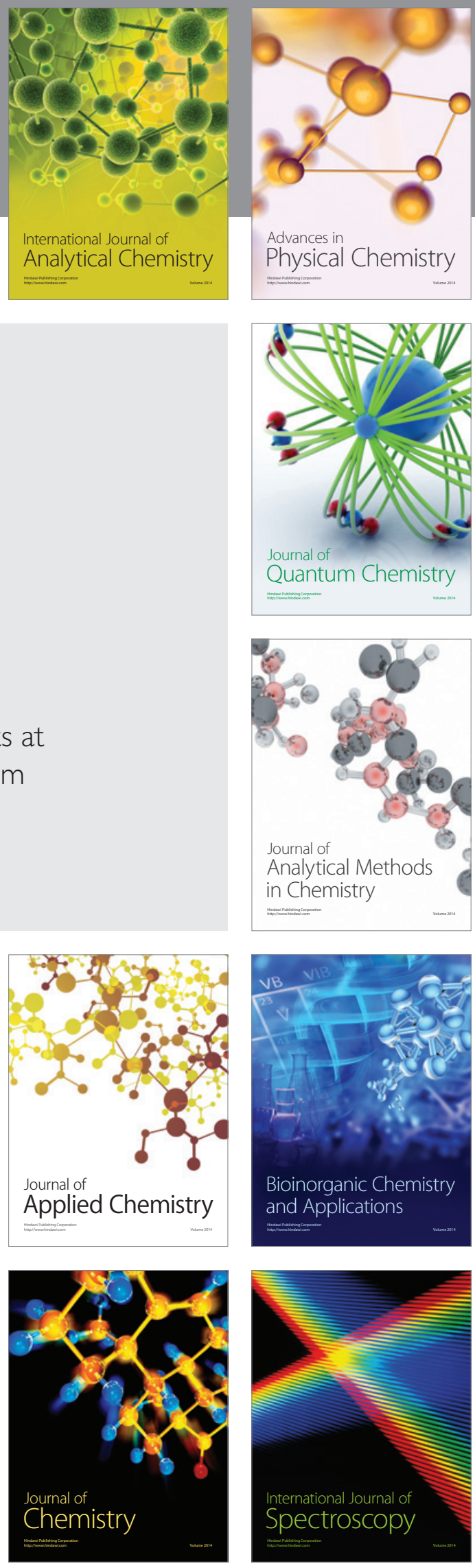